\title{
POTENTIAL ANALYSIS OF GAWAR GONG ECOTOURISM IN WANASABA DISTRICT, EAST LOMBOK REGENCY: DEVELOPMENT ENVIRONMENTAL LEARNING POSTERS
}

\author{
Abidatul Muthiah ${ }^{1}$, R. Didi Kuswara ${ }^{2 *}$, Ahmad Fadli ${ }^{3}$ \\ 1,2,3 Program Studi Pendidkan Biologi FKIP UNW Mataram \\ *Corresponding author, email: d0825059002@unwmataram.ac.id
}

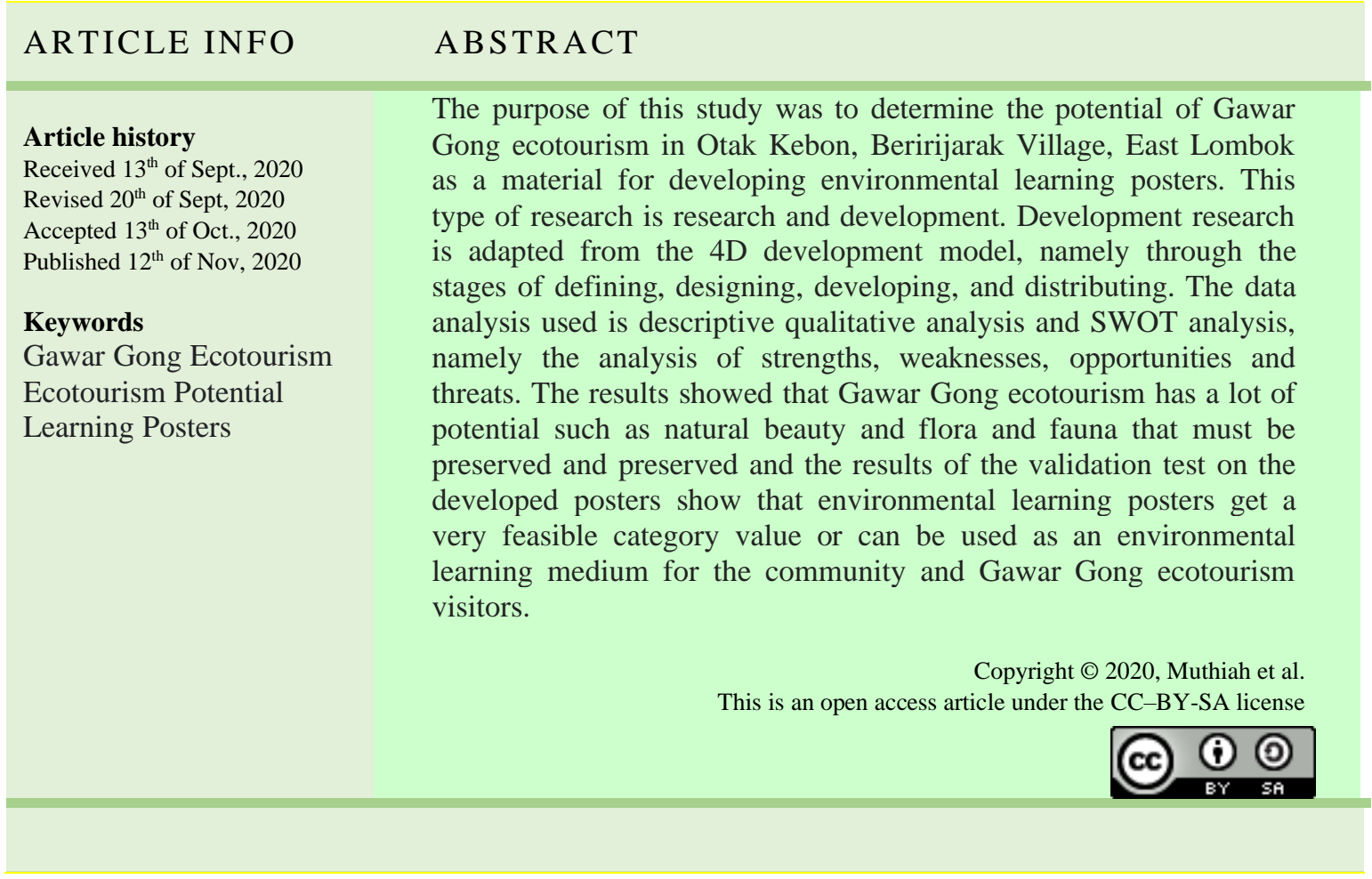

\section{A. INTRODUCTION}

West Nusa Tenggara (NTB) Province, especially in Lombok, has natural wealth such as mountains, lakes, beaches, hills and waterfalls, abundant biodiversity in the form of flora and fauna. According to Kuswara and Zulhariadi (2018) The development of tourism in a region or country is certainly one of the economic drivers of the community so that various types of tourism are developed starting from natural cultural tourism including environment-based tourism, namely "ecotourism". Ecotourism is a tourism activity that is responsible for nature, empowers communities, increases environmental awareness. The concept of ecotourism according to The International Ecotourism Society (2006), namely ecotourism is a responsible journey to natural areas that preserve the environment, support the welfare of local communities, involve environmental interpretation and education. Basically, ecotourism in its implementation is carried out with simplicity, maintains the authenticity of nature and the environment, maintains the authenticity of arts and culture, 
customs, habits of life, creates calm, maintains flora and fauna and maintains the living environment so that a balance between human life and the natural surroundings is created.

Ecotourism Gawar Gong is one of the nature conservation tourism located in Otak Kebon Hamlet, Beririjarak Village, Wanasaba District, the tour is managed by the local community. The author sees that Gawar Gong Tourism has various potentials for various natural beauty that need to be introduced, because there are still many people who do not know the potential it has. Among what visitors can enjoy in Gawar Gong nature tourism is a coffee plantation that is owned or managed by the local community and there are even products that can be marketed. Gawar Gong nature tourism also has a very wide forest and plants that are protected by the local village government, managers or youth of the Gawar Gong tourism village providing camping spots for those who want to camp and stay there.

Maintaining the natural ecotourism environment of Gawar Gong must be done by the community around the location itself, so that the naturalness or beauty of the place is maintained and can be enjoyed by future generations. Environmental care sometimes needs to be made to the community in a written way, one of which is by developing a poster about environmental learning for the community. So the authors will develop environmental learning posters for the community around Gawar Gong Ecotourism as an invitation to protect the environment. Therefore, the authors conducted research entitled "Analysis of the Potential of Ecotourism Gawar Gong Dusun Otak Kebon, Beririjarak Village, Wanasaba District to Develop Environmental Learning Posters".

\section{B. METHOD}

\section{First of Phase Research}

In connection with this research, the researcher will use a qualitative descriptive research method and also use a SWOT analysis to see the potential, strengths, weaknesses, opportunities and threats of Gawar Gong Ecotourism. This research was conducted using a survey method / initial site observation in July to see first hand the existing conditions. Furthermore, the data were obtained through a questionnaire through interviews. Interviews were conducted with managers or the community and visitors by asking oral questions that were arranged based on research interests. This interview refers to a list of questions compiled and considered in accordance with the potential aspects of Gawar Gong Ecotourism, so that it can add information to the results of the author's own analysis, so that the author can find out the potential that Gawar Gong has a complete natural ecotourism. And then the results of the research will later be developed environmental learning posters for the community.

Second of Phase Research: Development of Environmental Learning Posters. Environmental

Learning Poster Development Procedure refers to the 4D development model developed by S. Thiagarajan, Dorothy S. Semmel, and Melvyn I. Semmel. The 4-D development model consists of 4 main stages, namely: (1) Define, (2) Design (Design), (3) Develop (Development) and Disseminate (Spread), or adapt the 4-P Model, namely Defining, Design, Development and Deployment. 
a. Definition Stage (Define) The definition stage is a determination and meaning of the provisions in the product. In ensuring and determining the provisions that previously can analyze the intent of the poster being developed.

b. Design Stage (Design) The step of a goal is to prepare how the initial design (initial design) of a poster will be made or developed later.

c. Development Stage (Develop) In this development section where an arrangement or design of a poster is needed. If there is already a poster product that has been created or developed, a media expert will validate it by using a poster feasibility questionnaire to find out whether the poster that has been developed is feasible or not to be distributed.

d. Disseminate stage (spread) In this section, it is the stage for distributing posters that have been compiled by the author and validated by media experts, at the place that has been researched, namely Gawar Gong Ecotourism.

\section{RESULTS AND DISCUSSION}

\section{a. Gawar Gong Ecosystem}

1 Types of tropical rain forest with various types of plants surrounding, there are also springs.

2 In this village of Otak Kebon, there are still many rice fields which are community areas for growing various types of plants, such as rice, vegetables, tomatoes, etc. This provides a beautiful view because the rice fields there are terraced.

3 The river in this gawar gong is located under the forest area and camping area. This river is a rocky river with a water flow that is neither too heavy nor too deep.

\section{b. The Potentials of Gawar Gong Ecotourism}

\section{Protected Forest}

Gawar Gong is included in a protected forest that soothes the eyes and provides very fresh air. The Gawar Gong Protected Forest is one of the objects of ecotourism which is a source of living water capable of irrigating hundreds of hectares of rice fields, fields and drinking water sources for the community in Beririjarak Village and eight other villages. This forest is one of the main targets of the environmental education route or better known as replying. Studying in a free environment in the surrounding area, this activity aims to introduce biotic and abiotic environments. Introducing various types of plants and their benefits for this life will give children an understanding of the importance of preserving the environment so that later it will grow a generation that loves the natural environment.

\section{Camping Ground}

Gawar Gong as Ecotourism has a large enough area to provide camping or camping places for public visitors or schools who will hold events there such as scout inaugurations, nature lovers etc. This camping spot is available near the entrance to the Gawar Gong protected forest, making it easier to access.

\section{Follow the river}

For visitors who want to enjoy the Gawar Gong area with a different sensation, they can choose to go through the river path with the sensation of cold water. The manager will 
invite at the same time as a guide to walk along the river or what is commonly called in Sasak language "kokoq or sturdy".

\section{Rice terraced residents}

Gawar Gongs not only contain natural beauty such as waterfalls, rivers, forests but along the ecotourism entrance there are beauties such as terraced rice fields and towering green hills visible from a distance which can add to the beauty of the ecotourism atmosphere. The rice fields are owned by the community or residents around ecotourism.

\section{Coffee tree (the result of Beririjarak community coffee plantation / gawar gong ecotourism)}

For a long time, the results of coffee cultivators in Beririjarak Village, East Lombok are known for their delicious taste. As if they didn't want to lose to be one of the best coffee-producing villages, a group of youths who care about the environment calling themselves the Youth Movement for Change or abbreviated as GAPURA developed the results of coffee cultivators in East Lombok Regency, to be precise in Beririjarak Village, Wanasaba District.

The youth group develops local products for cultivators in their village, Kopi Rau is the original brand of Beririjarak Village. The coffee that is processed comes from the residents' fields in the Beririjarak Village. There are two types of processed coffee, which are packaged in several sizes, namely Arabica and Robusta. However, the most processed type is Robusta coffee because this type of coffee is mostly grown in this area.

The processing of coffee in Beririjarak Village by residents still uses the old method, namely frying the roast using a clay pan and made from fire from the protected forest wood of Gawar Gong itself.

\section{Numpas Water (Falls)}

In Gawar Gong Ecotourism not only has beautiful natural scenery, but Ecotourism Gawar Gong also has "Aik Numpas" or in Indonesian, namely Waterfall. The waterfall in Gawar Gong Ecotourism comes from a spill of water from the residents' rice fields and flows into the river.

\section{c. Flora and Fauna of Gawar Gong Ecotourism \\ 1 Flora}

In the protected forest of Gawar Gong, there are various types of plants, the most common of which are ferns. According to the results of the GAPURA (Youth Movement for Change) community survey a few months ago there were six types of ferns, namely Pterophyta, Nephrolepis cordifolia, Asplenium nidus and some were not. It is known the names and types of ferns in Latin or Indonesian (Primary Data, 2020). There are not only ferns but there are many types of plants that live in the Gawar Gong protected forest such as teak, sengon, mahogany, coffee, candle nut, and there are also forest strawberries and forest eggplant around the river.

\section{Fauna}

In addition to plants, various types of animals inhabit the Gawar Gong protected forest such as Lutung, lizard, long-tailed monkey, snake, monitor lizard, wild boar, Pepait Fish but the most dominant of the Gawar Gong Ecotourism fauna is the leech. The reason 
why leeches dominate in Gawar Gong Ecotourism is because Gawar Gong ecotourism has very high humidity and rainfall.

\section{d Gawar Gong Ecotourism SWOT Analysis \\ 1 Strength (Advantages of Gawar Gong Ecotourism)}

There are a lot of strengths or advantages that Gawar Gong Ecotourism has, but the author will only see through the point of view of its natural state and accessibility.

First; Ecotourism Gawar Gong has natural conditions that are very cool and unspoiled, so that many local people, not even a few residents outside the village, come to enjoy its beauty even if it's just a photo.

Second; Access to Gawar Gong Ecotourism is very easy because the place is close to residential areas.

\section{Weaknesses (Weaknesses of Gawar Gong Ecotourism)}

In discussing the weaknesses of Ecotourism Gawar Gong, the author will look at the infrastructure, supporting facilities and safety of the ecotourism.

First; The infrastructure and supporting facilities in Gawar Gong are still inadequate for visitors, for example, there is no bathroom / restroom available, so visitors or school children who are camping sometimes have a little trouble.

Second; unavailability of garbage dumps.

Third; The infrastructure such as the road to ecotourism itself has been on asphalt or repaired by the local government at the beginning of last year, previously the road was dominated by rocks so that it was a little difficult for visitors to go there.

Fourth; For your own safety, because in this ecotourism, there has not been a parking lot for motorbikes for visitors, so it can be said that it is not safe enough for visitors to leave their motorbikes.

\section{Opportunity (Opportunity of Gawar Gong Ecotourism)}

The opportunity that the writer wants to see from Ecotourism Gawar Gong is from the perspective of public awareness of what Gawar Gong Ecotourism has itself.

First; Ecotourism Gawar Gong has a great opportunity to improve the community's economy and the name of the village of Beririjarak Dusun Otak Kebon is due to the natural attraction that it presents. However, if this opportunity is not managed by the local government properly, the beauty of Ecotourism will be in vain.

Second; The existence of the coffee production itself from the plantations of residents around Ecotourism.

\section{Threat (Threat to Gawar Gong Ecotourism)}

Threats that need to be seen are environmental pollution and garbage.

First; Of the many visitors who come to visit Gawar Gong Ecotourism, sometimes some are not aware or lack awareness of the importance of maintaining a clean Ecotourism environment, especially in the Camping Ground section.

Second; Gawar Gong ecotourism includes quite high rainfall, sometimes heavy rain occurs, the rainwater can carry garbage to residents' settlements and scattered garbage can spoil the ecotourism landscape. 


\section{Result of Environmental Learning Poster Development}

The results of this research regarding the potential of Gawar Gong ecotourism in the Otak Kebon Hamlet of Beririjarak Village, the researchers developed an environmental learning poster, then to be distributed or installed in the ecotourism in order to invite the community to protect the ecosystem owned by Gawar Gong ecotourism. The poster development stage was prepared with the 4D development that was developed, namely through the defining, designing, and developing stages, and disseminating it. Then it was validated by media experts (Hanafi, M.Pd), and the fourth stage was the dissemination stage. Poster designs that have been developed are as follows Figure 3.1.

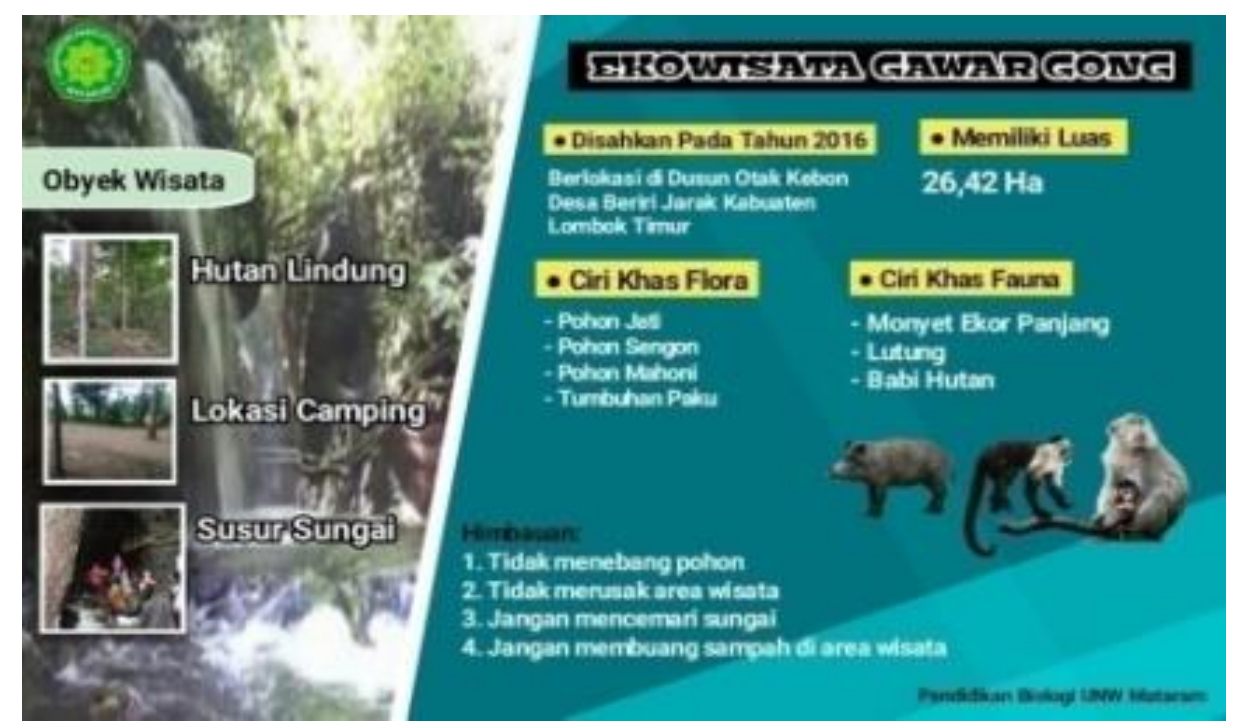

Figure 3.1. Poster Invitation To Protect The Environment Through Ecotourism Activities

Based on the table, the results of the validation by media experts were $87.5 \%$. The results of the validation test by media experts show that the environmental learning poster is in the very feasible category or can be used as an environmental learning medium for the community and visitors to Gawar Gong ecotourism.

\section{CONCLUSION}

Based on the results of the research that has been done, it can be concluded as follows.

1 Analysis of Gawar Gong Ecotourism Potential to develop Environmental Learning Posters was carried out because the researcher wanted to introduce Ecotourism located in Otak Kebon Hamlet, Beririjarak Village, Kec. Wanasaba, especially to the readers, is especially the researchers themselves, because Gawar Gong Ecotourism is not yet known to the general public about its natural beauty such as protected forests, camping areas, waterfalls (Aik Numpas), the diverse flora and fauna that exist there as well as various advantages, disadvantages, the threats and opportunities that Ecotourism has.

2 Based on Research Results The advantages of Gawar Gong Ecotourism include: 1) It has a natural state or landscape that is still natural and soothing to the eye. 2) Easy access to Ecotourism because it is close to residential areas. 3) Ecotourism Gawar Gong has potential beauty such as the existence of protected forests, waterfalls, camping 
spots. The weaknesses: 1) Lack of supporting facilities for visitors such as unavailability of bathrooms. 2) Unavailability of landfills. Opportunities that are owned: 1) Ecotourism Gawar Gong has the opportunity to improve the economy of the Beririjarak Village community because of the attractiveness that is presented. 2) There are coffee products (Robusta and Arabica coffee) from the plantations of the residents of Beririjarak Village that have been marketed. Meanwhile, Threat they have: Lack of awareness of visitors about the importance of cleanliness of the Ecotourism environment. 2) Ecotourism Gawar Gong has quite high rainfall, sometimes heavy rains will cause the rainwater to carry garbage to residents' settlements, and it can spoil the ecotourism landscape.

3 Development of Environmental Learning Posters was developed as a result of this research and also researchers want to invite visitors who come to protect the ecosystem in Gawar Gong Ecotourism through writing.

4 Based on the results of validation from the media expert validator, the percentage of eligibility of the poster is $87.5 \%$. This shows that the Poster is very worthy to be used or distributed.

\section{E. REFERENCES}

Kuswara, R.D \& Zulhariadi, M. 2018. Modul Ekowisata Berbasis Riset. Penerbit Nashir Al-kutub Indonesia, Mataram.

Kuswara, R.D \& Zulhariadi, M. 2018. Pengembangan Bahan Ajar Berbasis Riset Pada Ekowisata. ejournal.mandalanursa.org

Sugiyono. 2014. Metode Penelitian Pendidikan Pendekatan Kuantitatif, Kualitatif, dan $R$ $\& D$. Alfabeta: Bandung.

Sugiyono. 2015. Metode Penelitian Pendidikan Pendekatan Kuantitatif, Kualitatif, dan $R$ $\& D$. Alfabeta: Bandung

TIES (The International Ecotourism Society). 2006. Fact Sheet: Global Ecotourism. Updated edition, September 2006. www.ecotourism.org.

Wulan, C., Albayudi, A., \& Lidiarti, T. 2019. Analysis of Potential Ecotourism in the Rawa Bento, Kerinci District. Jurnal Silva Tropika, 3(1), 95-107.

Yuniarti, E., Soekmadi, R., Arifin, H. S., \& Noorachmat, B. P. 2018. Analisis Potensi Ekowisata Heart Of Borneo Di Taman Nasional Betung Kerihun dan Danau Sentarum Kabupaten Kapuas Hulu. Jurnal Pengelolaan Sumberdaya Alam dan Lingkungan (Journal of Natural Resources and Environmental Management), 8(1), 44-54. 